\title{
Beta-1 Adrenergic Receptor
}

National Cancer Institute

\section{Source}

National Cancer Institute. Beta-1 Adrenergic Receptor. NCI Thesaurus. Code C40096.

Beta-1 adrenergic receptor (477 aa, $\sim 51 \mathrm{kDa}$ ) is encoded by the human ADRB1 gene.

This protein plays a role in catecholamine-dependent $\mathrm{G}$ protein-coupled receptor signaling. 